\title{
Industrial production of natural gas in the North and Arctic regions of the Russian Federation and prospects for its implementation in the EU market
}

\author{
Mikhail Ulchenko ${ }^{1, *}$ \\ ${ }^{1} \mathrm{PhD}$ (Economics), Associate Professor, Leading Researcher, Editorial Department, G. P. Luzin Institute for Economic Studies of the \\ Kola Science Centre of the RAS, 184209, Fersman st., 146, Apatity, Russia
}

\begin{abstract}
The paper is devoted to the study of industrial production of natural gas in the regions of the North and Arctic of the Russian Federation and the prospects for its implementation in the market of the European Union. It is shown that the main production is concentrated in the Yamal-Nenets Autonomous district, where up to $75 \%$ of the total gas production is produced. Gas is transported both by means of a well-developed pipeline network connecting the Yamal Peninsula with European countries, and in a liquefied state, using gas carriers of the appropriate ice class. At the same time, despite all the efforts of the EU countries to reduce energy consumption, gas consumption is growing. This is due to the decline in production within the Union itself, as well as the desire to use more environmentally friendly energy sources. The analysis conducted in the course of the study showed that Qatar and Russia can actually increase the volume of deliveries in the near future. These exporters have a number of advantages that, in our opinion, will allow them to increase their presence in the energy market of the EU countries significant reserves of natural gas, availability of production capacity, opportunities to increase the volume of transportation, and the most attractive price for end users.
\end{abstract}

\section{Introduction}

Currently, the EU has 27 member States, which account for up to $25 \%$ of global GDP. At the same time, the volume of mineral fuel consumption is about 1,700 million tons of oil equivalent, of which 750 million tons (about 44\%) is covered by imports [1]. The largest energy supplier to the EU is the Russian Federation, which accounts for about $35 \%$ of the total volume of natural gas consumed by the Union countries. Given the significant reduction in gas production in the EU countries, as well as the rejection of coal, the demand for natural gas will continue to grow, even despite climate change. At the same time, the struggle for the EU market, between the main natural gas producers Algeria, Qatar, Norway, Russia and the United States, will continue.

\section{Industrial production of natural gas in the Russian Federation}

The Russian Federation ranks second in the world in terms of industrial production of natural gas - almost 738 billion $\mathrm{m}^{3}$ [2], at the end of 2019 , the us remains the leader -953 billion $\mathrm{m}^{3}[3]$. Figure 1 shows data on the volume of natural gas production in the Russian Federation since 1995. From the presented data, it can be seen that over the period from 1995 to 2019, the volume of production increased by $24 \%$ or by 142.8 billion $\mathrm{m}^{3}$. At the same time, the main part of production falls on the regions of the North and the Arctic zone of the Russian Federation, which are characterized by severe natural and climatic conditions of life [4].

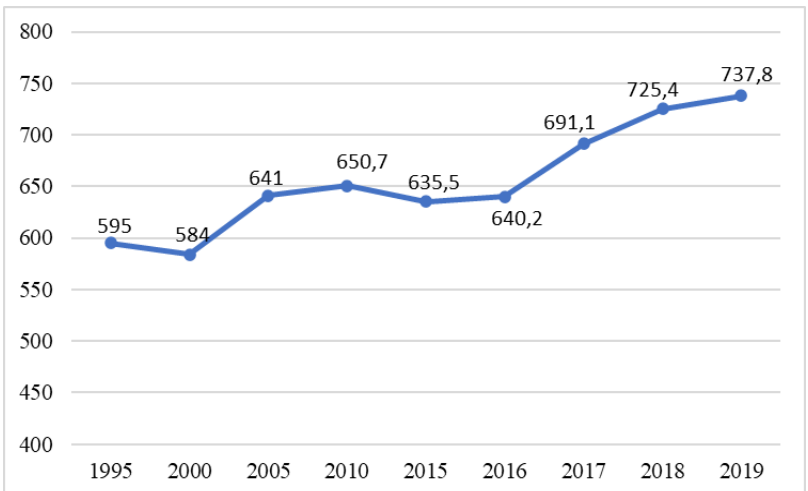

Fig. 1. Industrial production of natural gas in Russia, billion $\mathrm{m}^{3}[2]$

As one of the 8 regions that make up the Arctic zone of the Russian Federation, the Yamalo-Nenets Autonomous district is distinguished by both proven natural gas reserves-more than 26 trillion $\mathrm{m}^{3}$, and production volumes - more than 510 billion $\mathrm{m}^{3}$, according to the results of 2019. The main consumers of gas are the EU countries (UK, France, Germany and others) and Asia-

* Corresponding author: ulchenko23@rambler.ru 
Pacific region - China, South Korea, Japan. It is noteworthy that more than $93 \%$ of Russian Arctic natural gas is delivered to the EU via the pipeline system [5]. This project, which was named "Yamal-Europe", is considered a priority by the countries of the European Union, while the length of the gas pipeline itself is more than 4.1 thousand $\mathrm{km}$. The rest of the volume is delivered in a liquefied state using gas carriers. Currently, in the Russian Federation, PJSC NOVATEK is implementing a large Arctic project - Yamal-LNG (more than 16.5 million tons of gas per year), the uniqueness of which is that the production and liquefaction of natural gas is carried out in extremely low temperatures and permafrost. Separately, it is worth noting that the transportation of liquefied gas is carried out using ice-class gas carriers Arc-7, built within the framework of the designated project [6]. These icebreakers are able to independently, without icebreaking support, overcome ice jams up to 2 meters thick. The second major Arctic project, Arctic LNG, is next in line. The design capacity of this project is 3 lines of 6.8 million tons each. The launch of the first line is planned for 2024, the second and third for 2025 and 2026, respectively.

Given the volume of natural gas production and domestic consumption, it is safe to say that the Russian Federation is able to meet the growing demand for gas not only from the countries of the Asia-Pacific region, but also from the countries of the European Union.

\section{Industrial production of natural gas in the EU}

According to official data from Eurostat (figure 2), in the European Union, between 2010 and 2018, the volume of natural gas production decreased from 182 billion $\mathrm{m}^{3}$ to 119 billion $\mathrm{m}^{3}$, or by a third. Among the main reasons for the reduction in gas production is the decrease in production volumes at the largest field - Groningen, located in the Netherlands.

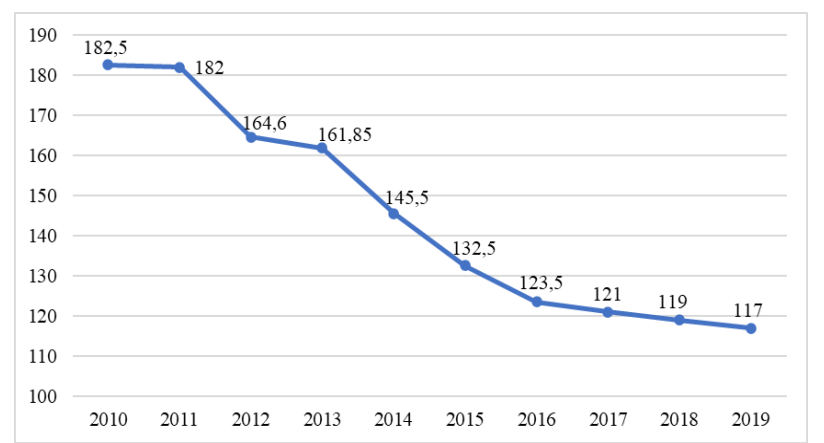

Fig. 2. Industrial production of natural gas in the European Union, billion $\mathrm{m}^{3}[1]$

The decline is planned and is caused by frequent earthquakes in the mining zone. According to the results of 2017 and 2018, the volume of production amounted to 24.2 and 20.1 billion $\mathrm{m}^{3}$, respectively. For comparison, in the period from 2009 to 2013 , it produced from 48 to 52 billion $\mathrm{m}^{3}$. As a result, the Netherlands became a net importer of gas for the first time in 2018. It is also necessary to note a three-fold reduction in the volume of natural gas production in the UK, caused by the depletion of fields. At the same time, the issue of developing shale gas fields in the $\mathrm{EU}$ is not even discussed.

In their quest to improve the environmental situation, EU countries are trying not only to reduce energy consumption, but also to replace coal with cleaner sources - wind, solar, water, and natural gas. This has led to the fact that the volume of consumption, as well as imports of natural gas, is constantly growing. Figure 3 shows data on natural gas imports by EU countries.

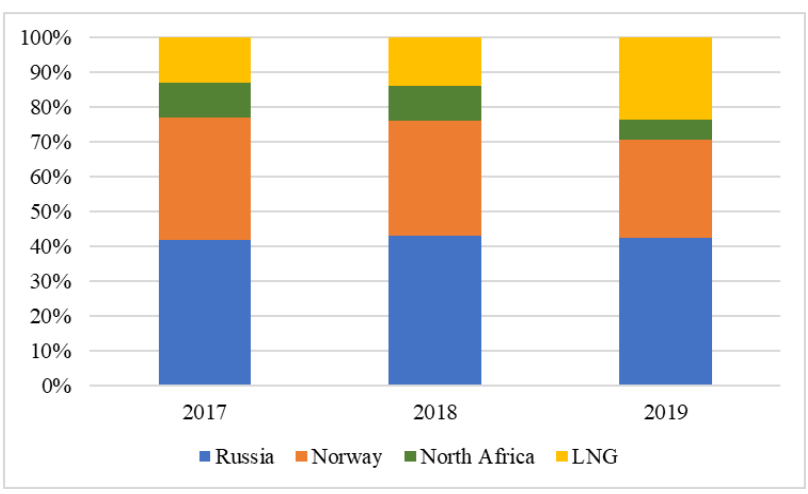

Fig. 3. Structure of EU gas imports [7]

The data presented in figure 3 shows that the main exporters of natural gas to the EU are Russia, Norway, North African countries (Algeria and Libya), as well as LNG producers. At the same time, the share of Russia in the total volume of EU imports remains at the level of $42-43 \%$, Norway and North African countries is declining, and LNG producers are growing. Since the situation in the energy market of the European Union countries is not so clear, additional analysis is required.

\section{Main natural gas suppliers and their prospects in the EU market}

Norway and Algeria, as the largest suppliers of natural gas to the EU countries, after the Russian Federation, faced a number of reasons that do not allow them to significantly increase their supply volumes in the near future. Norway is the second largest natural gas exporter to the European Union after Russia. However, Equinor noted a decrease in total gas production (by 2 billion $\mathrm{m}^{3}$ in 2018 and 6 billion $\mathrm{m}^{3}$ in 2019) and exports (by 4 billion $\mathrm{m}^{3}$ in 2018) in the last 2 years [8]. This is due to the exhaustion of large deposits, while new ones are located quite far from the coast, and they are not as productive, which affects the volume of production and cost.

Algeria, which has an impressive natural gas reserves of about 5 trillion $\mathrm{m}^{3}$ and a developed pipeline network connecting the country with Europe, is not able to significantly increase the volume of supplies due to constantly growing domestic demand [9]. So, in 2011, the country consumed about 32.3 billion $\mathrm{m}^{3}$, in 2015 
about 40 billion $\mathrm{m}^{3}$, and by 2025 , the consumption will reach the level of 54-56 billion $\mathrm{m}^{3}$. Among the largest producers and exporters of liquefied natural gas are Australia, Qatar, Russia and the United States.

Currently, Australia has the largest capacity for the production of liquefied natural gas, about 87 million tons. By the end of 2019, the volume of Australian LNG exports reached the level of 76 million tons, the main part of which (about $88 \%$ - 90\%) falls on the countries of the Asia-Pacific region. At the same time, in Australia itself, there is a paradoxical situation when gas prices inside the country are higher than export prices. This is due to errors in well productivity calculations. As a result, additional drilling increases the cost of gas, but it is not always possible to reach the required production volumes. Given the strict conditions stipulated in the supply contracts, some of the gas originally intended for domestic consumption is exported. Taking into account the distance to the EU countries, we can say that Australia is not able to compete with the main suppliers of LNG to European countries [10].

Qatar is considered the world's top LNG exporter. The annual export volume is about 77-78 million tons. Unlike Australia, Qatar's proven natural gas reserves are more than 20 trillion $\mathrm{m}^{3}$. Despite the fact that Qatari gas was originally intended for the countries of the AsiaPacific region, in an effort to diversify sales markets, Qatar Petroleum is actively promoting its LNG to the European market. The key advantage of Qatar is the presence of its own tanker fleet of about 70 vessels, as well as the low cost of gas production. Taking into account the fact that the Qatar Petroleum Corporation decided to increase production capacity to $110-115$ million tons, and construction of new gas carriers has begun, we can conclude that in 3-4 years Qatar will be able to significantly increase the volume of supplies of liquefied natural gas to the EU countries [10].

In the past 3-4 years, the US has constantly made statements about the expansion of the European gas market. It should be noted that the volume of American LNG exports for 2019 increased by more than $60 \%$ and reached the level of 33.75 million tons. This is due to the commissioning of new production lines with a total capacity of 27 million tons - Sabine Pass, Corpus Christi Pass, Freeport LNG. However, the fall in gas prices has led to the fact that no new production capacity is expected to be put into operation in 2020 and 2021. Moreover, we are talking about stopping existing production facilities. This is due to the high cost of American shale gas, as well as significant costs for its transportation.

Thus, we can say with a high degree of probability that Russia can actually increase the volume of natural gas supplies to the EU countries in the near future. Qatar, which has the largest tanker fleet, significant gas reserves and is actively increasing its production capacity, can compete with Russian gas.

The study was conducted under the theme "the Interaction of global, national and regional factors in the economic development of the North and Arctic zone of the Russian Federation" on the state assignment FITS KSC RAS.

\section{References}

1. European Statistics Database Eurostat. Available online: https://ec.europa.eu/eurostat/data/database (2020)

2. Ministry of energy of the Russian Federation. Production of natural and associated petroleum gas. Available online: https://minenergo.gov.ru/node/1215 (2020)

3. U.S. Energy Information Administration. Natural Gas Monthly. Available online: https://www.eia.gov/naturalgas/monthly/pdf/ngm_al l.pdf (2020)

4. V. Elistratov, The Ecological bulletin of Russia 11, 30-35 (2017)

5. P. Tcvetkov, D. Pritulyak, D. Tananykhin, In Journal of Physics: Conference Series 1072, 1, 012021 (2018)

6. S. Kozmenko, M. Ulchenko, IOP Conference Series: Earth and Environmental Science 302(1), 012123 (2019)

7. Observatory for Energy, DG Energy 11, 4 (2018)

8. The Norwegian Petroleum Directorate. Available online: https://www.npd.no/en/facts/publications/ (2020)

9. N. Didenko, D. Skripnuk, O. Mirolyubova, V. Merkulov, V. Sevashkin, E. Samylovskaya, International Conference on Information Networking, 217-222 (2018)

10. M. Ulchenko, The North and the market: shaping the economic order 1(67), 79-89, (2020) 